\title{
Engaging in the Struggle for Economic Justice in the Streets of the City of Tshwane ${ }^{1}$
}

\section{Dumisane W Methula ${ }^{2}$}

\begin{abstract}
The Meal of Peace Project is a transformative encounter that represents a theoretical break with neo-liberal missiological discourses and seeks to liberate the Bible from ivory tower hegemonic paradigms. This is done through Bible studies with the homeless from the City of Tshwane, engaging in the struggle for economic justice in the hills and valleys of Tshwane. In the past 20 years the major characteristic of the democratic dispensation in South Africa, since the inauguration of majority rule in 1994, has been the intensification of the country's socio-economic problems of poverty, unemployment and inequality. The struggle for economic justice is the new struggle for the prophetic church and liberation theologies in the current constitutional democratic juncture in post-apartheid South Africa. The need arises for exploring ethical alternatives to achieve economic injustice. This article's critical reflection on the socio-economic situation will be carried out through the Bible study session at TLF, where we looked at the message of Amos 5:22-24.
\end{abstract}

Keywords: Neo-Liberal, Contextual Bible Study, Tshwane, ecomic justice, prophetic church, liberation theology

\section{Introduction}

For as long as millions are still living in abject poverty in informal settlements - victims of commercial sexual exploitation and human trafficking, refugees and illegal immigrants, homeless and landless people, victims of abuse, of dehumanising materialism and opulence, with a profound lack of meaning - the task of nurturing a new consciousness, the drive to recover and reaffirm all humanity as sacred has not ceased to be important (De Beer 2008:2).

The whole purpose of the Meal of Peace Project, the Community Engagement project of the department of Christian Spirituality, Church History and Missiology, is to seek to nurture "a new consciousness and to

1 This article was published as a chapter in the peer-reviewed book Pavement Encounters for Justice: Doing Transformative Missiology with homeless people in the City of Tshwane (Mashau \& Kritzinger 2014), that was a result of the Meal of Peace Project of the Dept. of Christian Spirituality, Church History and Missiology at Unisa. The editors and the authors (as copyright owners), have given permission that this version may be published in Missionalia, as an accredited South African journal.

2 Pastor Dumisane W Methula, is a Research Assistant at the Department of Christian Spirituality, Church History and Missiology, at the University of South Africa (Unisa). Pastor Methula can be contacted at methudw@unisa.ac.za 
reaffirm humanity as sacred", as advocated by De Beer. This means concretely that theological reflection and mission praxis must be incarnated in the unfinished business of liberation that is incomplete. Since the black majority still live in informal settlements, they are "victims of commercial sexual exploitation and human trafficking, they are refugees and illegal immigrants, homeless and landless people, and victims of abuse'. And there are those forced into crime, substance abuse, alcoholic lifestyles and juvenile delinquency. At the root of these social problems lies the fundamental structural crisis of economic injustice and elite policies that only serve those with economic might, political power and social privileges. I concur with Mosala (1989:68):

Black theology will have to rediscover the black working-class and poor peasant culture in order to find for itself a materialist-hermeneutical starting point. The particularity of the black struggle with its different forms and faces must provide the epistemological lens with which the Bible can be read. Only this position seems to represent a theoretical break with dominant biblical hermeneutics; anything else is tinkering with what must be destroyed.

For Black theology to transform the future of Azania (South Africa), it must rediscover the voices of the black working-class, poor black peasants, black women, squatter camp residents, township young people and rural people in charting a new course of action. West (1991:19) says that in South Africa, as elsewhere, "the majority of interpreters of the Bible are not trained or semi-trained readers, but ordinary readers. More importantly, in South Africa most of these ordinary readers are from 'the base,' from the poor and oppressed." The Bible Study sessions conducted at the Tshwane Leadership Foundation with the homeless, abused women and the poor and economically oppressed people living in the streets of Tshwane sought to liberate the Bible from ivory tower theological discourses and to listen, learn and engage in the struggle with the voiceless on the economic periphery. I concur with West (1991:18) that "[w]hile the primary interlocutors of Western theology and biblical studies are educated and powerful, the primary interlocutors of liberation theologies are the poor and marginalized." In attempting to contextualise theological praxis, biblical studies and missiological reflection within the streets of Tshwane, our primary interlocutors and those with whom we seek to be in solidarity are the poor, landless, unemployed, underemployed, abused women, the homeless, street children, refugees and the victims of injustice. 


\section{Reflecting on the Context of Tshwane}

During his inaugural lecture, Mashau (2014:6) emphatically lamented the fact that the City of Tshwane "is a space of exclusion where the homeless, sex workers, foreigners, street vendors and many others who are on the margins are excluded from mainstream economy and socio-political landscape of our city. Most of them scramble for crumbs, just like Lazarus." The victims of economic injustice who are excluded from the mainstream economy are mainly black people, who still remain homeless, sex workers, criminal gangs and foreigners who came to the City of Tshwane looking for greener pastures from all over the country and the African continent.

Steve Biko (2012:61) challenged black ministers of the gospel to stop blaming "black people in the townships for their thieving, house-breaking, stabbing, adultery, etc. No one ever attempts to relate all these vices to poverty, unemployment, overcrowding, lack of schooling and migratory labour." 3 Black ministers of the gospel 20 years into democracy, instead of blaming young people and black people for car hijackings, violent crime, promiscuity, drug and alcohol abuse, must question the structure of economic injustice and land dispossession as producing these behavioural lifestyles in the democratic era. Ministers of the gospel must not maintain the status quo by condemning the poor for laziness, lack of faith and lack of hard work when in fact the socio-economic structure of society militates against young people, and especially young black women. One can only hope that the vision of the Executive Mayor of Tshwane will be achievable: "ensuring that the capital City of Tshwane by 2055 will be a liveable, resilient and inclusive city whose citizens enjoy a high quality of life, have access to social, economic and enhanced political freedoms and where citizens are partners in the development of the African capital city of excellence" (Ramokgopa 2014:10).

Engaging urban ministry twenty years after the democratic elections, this is what Mashau (2014:17) calls the City of Tshwane: "The city of hills and valleys. The hills of Tshwane continue to flourish and benefit from the system of the world." The hills of Tshwane symbolise political power, military might and economic affluence, whereas the valleys represent those who are economically powerless, politically weak, on the social margins, the poor, sex workers, foreigners, the homeless and street kids. With this painful reality in mind, Mashau (2014:10) says: "We can conclude, therefore, that life for the city dwellers in Tshwane very much resembles 'the valley of the shadow of death' of Psalm 23 and, to some extent, the dry bones in Ezekiel 37. Help is needed and is needed urgently."

3 Even though Biko made this statement during apartheid, its impact is still practically relevant currently in the post-apartheid era. 
Help is needed urgently because the situation of black people, particularly the majority, has changed little or become worse, irrespective of humanitarian initiatives like giving the poor free RDP houses, social grants and access to health and educational facilities. This happens, despite the fact that "Tshwane has the second-highest average household income in Gauteng - it is indeed above the South African average. Average household income in Tshwane has grown by almost 93\% since 2001" (Ramokgopa 2014:7). de Beer (2008:8) laments the fact that the streets of Tshwane are places:

where the belongings of the homeless people are stolen and burnt by security companies and police officers, where young prostitutes are bribed and women in general are harassed. The front pages of daily newspapers broadcast it: cash-in-transit robberies, hijackings and farm murders. But they seldom tell the stories of the countless acts of violence perpetrated against the most vulnerable in society by those who are supposed to protect them.

To restore the human dignity of the most vulnerable in the city, Ndungane (2005:2) says:

So it is right that the churches should be at the forefront of the fight against poverty, which, in all its ramifications and consequences, is nothing short of evil. It mars the image of God within humanity; it mars the image of God in the poor as it deprives them of opportunities for abundant life; and it mars the image of God within those of us who have more than enough, but who, through greed, complacency or even ignorance, fail to do the justice, to embrace the loving kindness that our God asks of us.

The poor in the city walk in the shadow of death and the streets of the City of Tshwane have become "sites of struggle between life and death;" they are the zones of non-beings where the homeless are "struggling in urban spaces, forever being under threat of eviction or removal, or criminalised for being poor" (de Beer 2014:1).

\section{Twenty Years of Institutionalised Poverty, Chronic Unemployment and Systematic Inequality in democratic South Africa}

In the past 20 years, the major characteristic of the democratic dispensation in South Africa, since the inauguration of majority rule in 1994, has been the intensification of the country's socio-economic problems of poverty, unemployment and inequality. It is important to acknowledge that, even though significant milestones have been attained in the political transition from the apartheid period to a democratic dispensation, the political transition and its successes should not be used to mask the contradictions that the democratic period embodies, especially with regards to questions 
about economic transformation and economic justice. The political compromises made in Kempton Park in 1993 had one ultimate objective: to subjugate, conquer and dominate blacks on the economic front.

The 1994 elitist transition did not transform the structure of economic injustice, the reason being that "racism is an institutionalised way of life in South Africa"4 Biko (2012:97). Furthermore, the EFF (Economic Freedom Fighters) say that "in the war for economic freedom, the black majority of Africans are still a conquered nation" (Shivambu 2014:3). This point is also acknowledged by the Executive Mayor of Tshwane, Kgosientso Ramokgopa (2014:6), in that "the role of the state in intervening in economic growth has often been hampered by market-led governance imperatives." Terreblanche (2012:101) writes:

All the social evils attached to abject poverty, structural unemployment and growing inequality negatively affect more or less the same section of the South African population: the poorest 25 million, of whom 95 per cent are African and 5 per cent coloured. The interaction between poverty, unemployment and inequality (PUI) not only entrenches and aggravates these people's predicament, but also intensifies their burden of deprivation

These social evils that entrench, aggravate and deepen deprivation among blacks are based on the fact that "the poorest 50 per cent still receive less than 8 per cent of the total income" (Terreblanche 2012:102). Cheap labour has been, and still is, a key fundamental feature of inequality and economic deprivation. This is manifested in unequal income distribution (expressed by a high Gini co-efficient), based on racially-distorted economic structures that reinforce South Africa's notoriously-earned status as the most unequal society in the world. In this country, people live side by side in extreme wealth and extreme poverty. The question is: Is democracy and the world-acclaimed constitution of South Africa all about entrenching cruel inequalities, institutionalising poverty and growing an economy that does not create jobs? The fact that predominantly white suburbs are like "First World Countries" in terms of income, infrastructure, lifestyle, property, resources, economic power, social privileges etc., whereas townships are like "Third World Countries" characterised by crime, poverty, hunger, deprivation, squatter camps, health hazards and poor quality education, makes one agree with the conclusion of the former president of South Africa, Thabo Mbeki that we are not one nation, but two nations in one country. Ndungane (2013:1) comments:

The World Bank reports that, even though economic growth and rising social welfare payments have made a dent into poverty levels in South Africa, large pockets of poverty remain deeply entrenched,

4 Though legally racism ended formally with apartheid in 1994, the very structure of post-apartheid society is anti-black in more sophisticated ways. 
mostly among the black population in townships and informal settlements. An estimated $34.5 \%$ still lives below the poverty line, while a large number has relied on grants as a safety net and a single source of income to stay on or slightly above the poverty line. Some data sources state that as much as $50 \%$ of the population lives below the poverty line, if the international poverty line of $\$ 2$ a day is considered. Two dollars a day is equivalent to R606 per person per month using today's prices. Take a moment to think about what you would be able to afford with R606 each month.

Biko (2012:102), in analysing the socio-psychological state of blacks, said: "The most powerful weapon in the hands of the oppressor is the mind of the oppressed." According to Mosala (2010:5), "after years of liberal ideological domination of the opposition space, it was BC [Black Consciousness] that exposed the hypocrisy and moral bankruptcy of liberalism and liberals. BC unseated liberalism; it drove it into exile; it liberated our people from its seductive appeal." The reason why the ANC-led government from 1994 till 2014 has never championed the culture of entrepreneurship, self-reliance, the spirit of innovation and quality service delivery for the black majority is simply because of its reliance on the "hypocrisy and moral bankruptcy of white liberalism and black liberals." The problem is that we are politically free, but our minds are not decolonised. Vellem (2013:5) says:

The dominion of market fundamentalism - the central place that has been given to neoliberal economics post-1994 - which continues to disembowel the poorest of the poor is a form of religion we can only welcome by betraying the gospel of Jesus Christ. The hegemony of pragmatic politics which has resulted in a skewed logic of justice does not only render our reconciliation discourse post-1994 'heretical,' but also dislodges our theology from its foundational interlocutor, while market fundamentalism attains a pseudo-religious status.

We cannot remain the church of those on the margins by embracing neo-liberal policies that "continue to disembowel the poorest of the poor and betray the prophetic mandate of the gospel of Jesus Christ." Why we have the structural problems of poverty, unemployment and landlessness is because of the myth of reconciliation and non-racialism based on dependence on white people. Hence, as blacks we cannot create employment, grow the economy, build an infrastructure and give quality basic services without the white people. The reason is that we are psychologically not liberated, but still in spiritual, scientific, theoretical and economic bondage to white people and Euro-American epistemological paradigms. 


\section{Exploring Ethical Alternatives to Economic Injustice}

I understand the struggle for economic justice as a need for a redistribution of wealth and land to address past injustices and restore the dignity of those on the margins, but this struggle must be founded on moral values, ethical principles and biblical justice for the widow, stranger and orphan. Thus, the struggle for economic justice is a search for more just, equitable and sustainable economic alternatives that are founded on the common good, solidarity, preferential options for the poor, democratising the economy and bringing the fulness of life to the majority of black citizens who have lost their land and economic wealth underneath the soil through colonialism and apartheid. As a matter of fact, it is imperative for the Black/African Christian Church and Black Theology to subject every economic system to the demands of the gospel based on human rights, human dignity, a just social order and a shared vision for development, equity, based on liberation, justice, shalom and the Reign of God. Vellem (2013:5) says: "I submit, therefore, that faith in its crudest sense in neo-liberal economics must be repudiated. There are many similarities between GEAR ${ }^{5}$ [Growth, Employment and Redistribution] and NGP $^{6}$ [New Growth Path] such as tight fiscal measures and, indeed, its 'eschatological' promise for the poor and jobless."

The Black theological praxis of liberation in the struggle is to search for an alternative economic system founded on economic reconciliation that prioritises the victims of colonialism and apartheid. It must re-open the debate on the merits and de-merits of capitalism, socialism and social democracy. The economic situation of South Africa therefore has to be evaluated in order to develop ethical and theological options for a just and life-giving economy. Twenty years after the dissolution of apartheid and the establishment of the democratic dispensation, this analysis calls for a radical rethinking of economic justice - drawing insight from theology, ethics, economics and social experience. Not only do we need to criticise neo-liberalism, economic globalisation and capitalism, but we also need to develop a Black theological theory of economic justice that explores alternatives to socio-politico-economic liberalism that aggravates economic injustice. Yet in the process, with other organic intellectuals committed to Black Consciousness ideas and Pan Africanism, we must engage in developing African socialism as a theological and economic paradigm of justice in the twenty-first century.

5 GEAR was the neo-liberal macro-economic policy adopted by the ANC- led government in 1996 that was based on market fundamentalism.

6 NGP, adopted as the macro-economic policy of the Zuma administration, is not radically different from GEAR in that it is still a neo-liberal market fundamentalist policy. 


\section{The Economic Justice Challenge from the Book of Amos 5:21-24 and the Experiences of the Homeless and Abused Women in Tshwane Leadership Foundation}

Listening, engaging, discussing and reflecting on the theological challenge from the Book of Amos 5:21-24 in the Bible was a humbling experience, a learning curve and a new journey of faith based on the academy of ordinary readers of the Bible. Their interpretation of Scripture continuously reminded me to be a listener, learner and student, to sacrifice my teacher complex, and listen to new paradigms informed by the epistemological privilege of the homeless and abused women. I was reminded about the birth of liberation theologies in the 1960s - that these theologies were not born in lecture halls, seminaries, theological faculties or church councils. Instead, liberation theologies were born in the struggles of the poor in the streets of the major cities of the world, where they prioritised transformative actions, rather than merely interpreting theology.

To the homeless, abused women, commercially exploited sex workers, street children, foreigners and victims of economic injustice - those on the margins of society - poverty is not a theoretical, abstract or scientific question, but a daily reality. To them, homelessness is not just some statistics, but the painful reality of: Where do I sleep tonight? Where is my next meal going to come from? And the pain of having left family in the rural areas to look for greener pastures in the capital city of South Africa. This is also a reality for the migrants from other countries like Zimbabwe, Mozambique and elsewhere in Africa who are looking for better opportunities in South Africa. During the Bible Study, we reflected on the selected verses in the Book of Amos, dealing with the themes of worship, wealth, righteousness and justice, which form the basis of the struggle for economic justice within the biblical paradigm. Before I discuss the interpretation of homeless and abused women, it is important first to reflect, understand and unpack the challenge of social justice contained in Amos 5:21:24.

The Bible is full of passages that place the call for justice in the centre of its teaching. Justice is an important issue in all societies and it is a central theme in Christian theology. Justice and righteousness are synonymous terms grounded in God's divine nature, revealed in God's law and covenant. The words justice and righteousness abound in biblical passages with a prophetic perspective. I agree with Van Heerden (2011:74) that the prophets of Israel:

were not primarily interested in abstract philosophical issues, nor in definitions and intricate arguments. They speak about the lot of simple people - widows, orphans, aliens. They also speak about the daily conduct of the rich, public officials and heads of state. The 
prophets felt intensely about injustice and their oracles were their way of expressing their agonised struggle over it.

Justice, right and righteousness are concrete practical concepts that emphasise the importance of doing justice, not mere abstract theoretical issues or merely just rational thinking. Two words from the Scriptures are translated by the word justice - mishpat (justice, judgement) and tsedaqah (righteousness, justice). Tsadiq, referring to the one who practises justice and righteousness, is at the centre of the teaching of the prophets.

In liberation theologies, justice is clearly associated with a special concern for correcting historical injustices for the poor, the oppressed and those who lack the means of self-sustenance. Dolamo (2001:293) says that "Justice is based on equal rights and equal dignity. Justice based on these two concepts implies a social balance." In discussing the biblical, theological and ethical context to the Book of Amos, I do not mean to impose my views nor dictate my understanding of Scripture to the homeless and the abused women, but to contextualise this passage so that we can appreciate the views from below, as expressed on the streets of Tshwane. Doorly (1989:18) explains that:

The eighth-century prophets are the first biblical characters without a veil of myth and legend. Hosea, Amos, Isaiah and Micah do not perform any miracles, and, apart from some Isaiah narrative, do not play a key role in the nation's history. They are not presented as deliverers of the people, nor are they pictured as being in positions of great importance in the nation's history.

By the middle of the eighth century BCE, when Amos was called as a prophet to the northern kingdom, he was a stock trader from Tekoa in Judah. Van Heerden (2011:79) sets the scene: "It was a time of reasonable prosperity and political stability, but also of grave social abuses. The poor were the prime victims of these. The people with economic power were the ones that were most insensitive to the lot of the poor." The situation was so unjust in the northern kingdom that the Israelites "sell the righteous for silver, and the needy for a pair of shoes" (Amos 2:6, 8:6). Amos could not tolerate such miscarriage of justice, for the poor were quite shamelessly exploited by those with economic power. The courts of justice and those with political authority trampled on justice and served the status quo.

The price increases forced the poor peasants to borrow money and pledge their properties to make a living until they had lost the land and were forced to work on their property - their land - for somebody else (Doorly 1989:44; Kelley1973:43; Van Heerden 2011:79). Ultimately, the poor were sold into debt slavery (Amos 2:8). That led to a situation where the poor were working for someone else on what had been their own land, simply in order to meet their commitments to their creditors. Eventually, some of the poor were sold into 
debt slavery, as people who were enslaved for non-payment of debt were often sold to foreigners. Such people could rightly claim to have lost everything (Amos 2:6; 8:6), (van Heerden 2011:79). In that context of injustice, Amos 5:21-24 exclaimed in God's name:

I hate, I despise your feasts, and I take no delight in your solemn assemblies. Even though you offer me your burnt offerings and cereal offerings, I will not accept them, and the peace offerings of your fatted beasts I will not look upon. Take away from me the noise of your songs; to the melody of your harps I will not listen. But let justice roll down like waters, and righteousness like an ever-flowing stream (ESV 2013).

Motyer (2005:130-131), commenting that this passage reveals the practice of a "wealth religion" consisting of festivals, sacrifices, and music - all evidence of abundance. They took their religious duties seriously; they entered fully into their religious privileges, bringing burnt offerings, cereal offerings, and peace offerings symbolic of their status as God's people. They gave full expression to their religious joys with singing... but all that God heard was noise. Van Heerden (2011:80) says "The prophet [Amos] maintains that the people's religious celebrations were abhorrent while injustice was rife among them. The Lord is not to be simply 'celebrated;' he wants to guide the people towards greater justice and righteousness." This is confirmed by Kelly (1973:85): "Verse 24 might well be called the golden verse of Amos, for it sounds the keynote for the entire book. [Amos] had caught a vision of a just society, a society in which religion was no longer a matter of rites and ceremonies, but where the true service of God was the service of the poor and the oppressed."

The justice which is the fruit of righteousness is not some psycho-spiritual matter, concerned about the personal prosperity of individuals. This justice is a social, political and economic one that removes obstacles that bind the poor, unemployed and landless people to poverty. The God of justice is not found in wealthy religious festivals where justice is neglected, but demands equality among human beings.

During the Bible Study at TLF, we looked at the following question: "Why does God reject the fat and rich offerings of those who practise economic injustice, political corruption, abuse of state power, gender oppression and self-enrichment"? During the group discussions, participants felt that "God is righteous and therefore he dislikes people doing things from an evil heart. God does not want offerings from rich people who oppress and exploit poor people." These observations by the homeless and the abused women are critical in constructing urban local theologies, because the voices of the poor are critical and serve as the formative and foundational basis of Black and liberation theologies. The righteousness of 
God is raised within the fact that God is a God of justice who protects the poor, widows and strangers. The fact that the group speaks about "God rejecting the offerings of rich people who oppress and exploit the poor" is a great observation. The group members also felt that "rich and powerful people make offerings to impress." They argued that "these kind of offerings are meant to silence the ministers of religion from being critical of economic injustice against the invisible members of the community, whose rights are trampled upon by the rich people who bring fat offerings, not out of a genuine heart, but rather to impress others and trash the poor as the lazy ones." One participant said: "the dominant theme in the Book of Amos is social justice."

During the group discussions, participants said that "social equality means us being equal in the eyes of God." Group members stated that "true worship leads to social equality, shalom and the Reign of God, but where there is no equality, the righteousness and justice of God is absent and there is only the noise of worshippers. The members in the Bible Study groups made the comments that "Justice is like the flowing of a stream and righteousness is like a river that never runs dry. God knows how the rich have prevented the poor from justice." Considering the discussion by the homeless and the abused women, they observed that "justice is like the flowing of a stream that must not be prevented or poisoned by political corruption, abuse of state power and economic inequalities." They concluded by saying "Righteousness, which is the fruit of justice, must be like a river that never runs dry, for when it runs dry the poor suffer homelessness, women are abused, workers are underpaid, and social justice is perverted."

\section{Conclusion}

We must continually be engaging in the struggle for economic justice side by side with the victims of injustice, and be in solidarity with those on the streets of Tshwane begging for bread, sleeping in inhuman conditions. We must also form partnerships with abused, violated and enslaved women, foreigners and homeless people. From this Bible study, the major themes of social justice and God's righteousness can be developed to engage in the holistic struggle for economic justice in the streets of Tshwane. Any solution to the problems of homeless and abused women must be based on the agency of those on the social margins. The voices of the untrained readers of the Bible must inspire and direct the vision and mission of Black Theology in the current elitist and neo-liberal democratic dispensation. We must explore alternatives to capitalism and break with the dominant bourgeois ideology and the morally bankrupt neo-liberal hegemonic

7 The group members made most of their comments in African languages, and their comments carried more weight, power and deep conviction. 
discourses in post-apartheid South Africa. The eschatological message of Christ's liberation must be incarnated in the struggles of informal settlements, victims of commercial sexual exploitation, human degradation, dehumanised voices on the margins and illegal immigrants.

\section{Bibliography}

Biko, S. 2012. I write what I like. Picador Africa, Johannesburg.

Dolamo, R. 2001. Reconciliation and Economic Justice in South Africa: the Role of the Church and Theology. Verbum et Ecclesia 22(2): 292-299.

De Beer, S. 2008. "Taking Back our Streets": Reading Steve Biko's "Black Consciousness and the Quest for Humanity" on the Streets of Tshwane. Paper presented at the Forum for Religious Dialogue Symposium of the Research Institute for Theology and Religion held at the University of South Africa, Pretoria, 23-24 August 2008 www.uir.unisa.ac.za (Accessed 27 June 2014) 1-17.

De Beer, S.F. 2014. Between Life and Death: On Land, Silence and Liberation in the Capital City. HTS Teologies Studies/Theological studies 70(1), Art.\#2075, 7 pages. http://dx.doi.org/10.4102/ hts.v70i1.2075 (Accessed 06 Nov. 2014).

Dourly, W.J. 1989. Prophet of Justice: Understanding the Book of Amos. Paulist Press,.

Kelly, P.H. 1973. Amos: Prophet of social justice. Baker Book House, Grand Rapids, Michigan.

Mashau, T.D. 2014. Reimagining Mission in the Public Square: Engaging hills and valleys in the African City of Tshwane. HTS Teologiese Studies / Theological Studies; 70(3) (2014), 11 pages. doi: 10.4102/hts.v70i3.2774 (accessed 11 Nov 2014).

Mosala, I. 1989. Black Theology and Biblical Hermeneutics in South Africa. Grand Rapids: Eerdmans .

Mosala, I.J. 2010. A paper delivered by Prof Itumeleng Mosala at the AZAPO 20th National Congress held at the Fun Valley Conference Centre in Johannesburg on 20 March 2010.

Motyer, A. 2005. The Message of Amos. InterVarsity Press, England.

Ndungane, N. 2013. Good Governance Conference. www.africanmonitor.org/ampresidentspechees (accessed 2014: 05-12). 
Ramokgopa, K. 2014. State of the Capital City Address. www.tshwane.gov.za/speeches\%20City\%Address\%20\%2003April \%20\%FINAL\%version.pdf (Accessed 28 Oct 2014).

Shivambu, F. 2014. The Coming Revolution: Julius Malema and the fight for economic freedom. Auckland Park, Jacana.

Terreblanche, S. 2012. Lost in transformation. Johannesburg, KWW Review Publishing Company.

Van Heerden, W. 2011. Poverty and Prophetic Critic, in The Bible and the Eradication of Poverty, Scheffler, E and van Heerden W (eds). University of South Africa, Tshwane (Pretoria).

Vellem, V. 2013. A critical black analysis of the church's role in the post-apartheid struggle for socio-economic justice. Studia Historiae Ecclesiasticae 39(2) Feb, www.scielo.org.za (accessed 28 June 2014) 1-23.

West, G. 1991. Biblical Hermeneutics of Liberation: Modes of Reading the Bible in the South African Context. Cluster Publications, Pietermaritzburg. 